\title{
Oncogenic high-risk human papillomavirus in patients with full denture
}

\section{Alessandra Cardoso da Silva NASCIMENTO(a) \\ Mariana Calarge NOCETTI(b) Larissa Zatorre Almeida LUGO(c) Camila Mareti Bonin JACOB(c) \\ Ana Paula MACHADO(d) (iD Cacilda Tezelli Junqueira PADOVANI(b) (D) Alda Maria Teixeira FERREIRA(b) Carlos Eurico dos Santos FERNANDES ${ }^{(b)}$ (i) Inês Aparecida TOZETTI(d) (D)}

(a) Universidade Federal do Mato Grosso do Sul - UFMS, School of Medicine, Post-graduate Program of Health and Development of the Center Western Region, Campo Grande, MS, Brazil.

(b) Universidade Federal do Mato Grosso do Sul - UFMS, Institute of Biosciences, Campo Grande, MS, Brazil.

(c) Universidade Federal do Mato Grosso do Sul - UFMS, School of Medicine, Post-graduate Program of Infectious and Parasitic Diseases, Campo Grande, MS, Brazil.

(d) Universidade Federal do Mato Grosso do Sul - UFMS, Institute of Biosciences, Multicentric Postgraduate Program in Biochemistry and Molecular Biology, Campo Grande, MS, Brazil.

Declaration of Interests: The authors certify that they have no commercial or associative interest that represents a conflict of interest in connection with the manuscript.

Corresponding Author:

Inês Aparecida Tozetti

E-mail: inestozetti65@gmail.com

https://doi.org/10.1590/1807-3107bor-2019.vol33.0091

Submitted: December 13, 2017

Accepted for publication: August 21, 2019

Last revision: August 28, 2019
Abstract: Human Papillomavirus (HPV) has considerable tropism for epithelial and mucosal tissues and can therefore be found in several anatomical sites, including the oral cavity. This study aimed to investigate the presence of HPV-DNA and the most frequent viral types in patients using full dentures, compare to patients not using full dentures and to associate its presence with socio-epidemiological and behavioral factors. The study consisted of 90 patients with or without full dentures at the time of collection, treated at a public dental clinic. The samples were obtained by exfoliating the oral cavity, and analyzed for HPV-DNA using the nested PCR with PGMY09/11 (450-bp), and general primers GP5+/GP6+ (150-bp). Genotyping was performed by specific-type PCR to HPV 6, 11, 16, 18, 31, 33, and 45; and Restriction Fragment Length Polymorphism (RFLP). Pearson's Chi-square test $\left(x^{2}\right)$ or Fisher's exact test were applied and significant variables in these tests were analyzed by multinomial logistic regression analysis to estimate odds ratio (OR). HPV-DNA was detected in $27.7 \%$ of samples and, among those obtained from patients using full dentures, positivity for HPV-DNA was $41.9 \%$ ( $p=0.025$ ). The most frequent viral types were low-risk HPV 6 and 11, and highrisk HPV 31 and 45. Patients who used full dentures had an odds ratio of 2.1 to be positive for HPV DNA. Our results indicate the need for periodic dental follow-up of patients with full dentures in order to preserve the basic conditions of oral health, and also to monitor the appearance of lesions with malignant potential.

Keywords: Oral Health; Papillomaviridae; Polymerase Chain Reaction.

\section{Introduction}

Human papillomavirus (HPV), particularly the genus alpha papillomavirus, has considerable tropism for epithelial and mucosal tissues. Therefore, it can be found in several anatomical sites, including the anogenital tract, larynx, esophagus, oral cavity, and others, causing disease ranging from benign lesions, such as epithelial warts, to malignant neoplasms. ${ }^{1,2}$ In recent decades, there has been a marked increase in cases of HPV infection among men and women. ${ }^{3,4} \mathrm{HPV}$ infects the basal cell layer of the epithelium, leading to micro trauma at most instances, which causes the basal cells to be exposed and susceptible to virus entry. ${ }^{5}$ 
The methods of transmission of the virus into the oral cavity have not yet been fully elucidated; some theories point to the importance of vertical transmission, self-inoculation, common use of fomites, and oral sex. The latter has been considered the main form of infection acquisition in the oropharyngeal region. ${ }^{6}$

Although HPV infection is mainly considered to be sexually transmitted, it is also known to be multifactorial because risky behaviors such as high number of sexual partners, smoking, alcoholism, and exposure of the oral mucosa to frequent traumas (like those caused by the use of full dentures) can facilitate infection. $5,7,8,9,10$

To date, more than 200 types of HPV have been identified, which can be classified according to their oncogenic potential as high oncogenic risk (HR-HPV), including HPV 16, 18, 31, 33, 35, 39, 45, 51, 56, and 58, and low risk (LR-HPV), including HPV 6, 11, 42, 43, and $44 .{ }^{9,11}$ More than 30 types have been isolated in oral lesions or in oral mucosal infections, among which the most frequent are HPV 1, 2, 3, 4, 6, 7, 10, 11, 13, 16, $18,20,28,30,31,32,35,38,40,45,52,54,55,57,58,59$, $68,69,72,73,77$, and $85 .{ }^{12}$ Seven of these types (HPV $6,11,16,18,31,33$, and 35) have also been isolated in healthy oral mucosae. ${ }^{13,14,15}$

Epidemiological studies have found clinical correlation with secondary factors such as poor oral hygiene, excessive exposure to sunlight, injuries caused by lacerated and pointed teeth, and poorly adapted dentures, thus increasing the susceptibility for HPV infection. ${ }^{16,17,18,19}$

Because of the importance of this virus during the carcinogenesis process, the objective of this study was to investigate the presence of HPV-DNA and the viral types most frequently found in patients with full dentures, and to make an association with the socio-epidemiological aspects and behavioral factors that expose them to infection, which defines the risk of this group for developing HPV infection.

\section{Methodology}

\section{Population study and design}

This was a cross-sectional, quantitative study with non-probability sampling - a convenience sample. The subjects involved in the study were patients treated at the Faculty of Dentistry of the Federal University of Mato Grosso do Sul, in Campo Grande city, the Center-Western Region of Brazil, from October 2014 through October 2016. The inclusion criteria were patients of both genders aged 30 years or greater, with or without full dentures. The sample size was obtained considering the case series of the Faculty of Dentistry, corresponding to $15 \%$ of the patients attended during the period.

Ethical approval was granted by the Ethics Committee in Research of the Federal University of Mato Grosso do Sul, protocol no. 36389814.2.0000.0021 on 30/09/2014. All participants filled in a questionnaire containing information regarding risk behaviors that may predispose them to HPV infection.

\section{Collection of specimens and detection of HPV-DNA}

Samples were collected through 5-10 brushings from pre-established regions of the oral mucosa including the right buccal mucosa (position from top to bottom); left buccal mucosa (position from top to bottom); right, left, and dorsal side of the tongue; and inner regions of upper and lower lips. After collection, DNA was extracted from the samples using the phenol chloroform technique, and quantified using a NanoDrop (Thermo Scientific, Waltham, MA, USA) (180-260 nm). HPV-DNA detection was performed by nested PCR with a pool of consensus primers that amplify PGMY09/11 450-bp DNA sequences within the $\mathrm{L} 1$ region of $\mathrm{HPV}$, and general primers GP5+/GP6+ (150-bp) as described previously. ${ }^{20}$ An endogenous control was used to verify DNA integrity using primers for the human $\beta$-globin gene, PC04 and GH20, which amplify a 286-bp sequence. Negative controls for background contamination were added to the DNA template. PCR products were analyzed using 1.5\% agarose gel electrophoresis with ethidium bromide staining to visualize the DNA under ultraviolet (UV) light. Molecular weights were determined by comparison with a 100-bp DNA ladder.

\section{Genotyping}

HPV-DNA-positive samples were genotyped by PCR using type specific-PCR (TS-PCR) for the 
DNA sequences of the E6 and E7 genes of LR-HPV 6 and 11, and HR-HPV 16, 18, 31, 33, and 45. ${ }^{21}$ PCR products were analyzed in a $2.5 \%$ agarose gel followed by ethidium bromide staining to visualize the DNA under UV light. Molecular weights were determined by comparison with 100bp and 50-bp DNA ladders. Restriction fragment length polymorphism (RFLP) was used for samples that were positive for HPV-DNA by PGMY09/11 primers. The PGMY 09/11 PCR product of these samples was purified from the agarose gel using a QIAE X II Gel Purification kit (Qiagen, Dusseldorf, Germany), according to the manufacturer's protocol. The concentration of the extracted material was measured using a NanoDrop, and samples with sufficient material $(4.0 \mathrm{ng} / \mathrm{ml})$ were subjected to enzymatic digestion for $1 \mathrm{hr}$ at $37^{\circ} \mathrm{C}$. The enzymes used for the reaction were DdeI, HaeIII, RsaI, and PstI. The digestion pattern obtained was analyzed under UV light and interpreted using an algorithm previously described in the literature. ${ }^{22}$

\section{Statistical analysis}

SPSS 10.0 (SPSS Inc., Chicago, IL) software was used for statistical analysis. For data comparison, Pearson's Chi-square test $\left(x^{2}\right)$ or Fisher's exact test were applied; for analysis of the variables 'use of full denture' and 'oral sex practice', the test of binary logistic regression was applied.

\section{Results}

\section{Prevalence of infection}

The study involved 90 patients, mean age of 49.2 years (30-80 years), 36.7\% (33-90) males and 63.3\% (57-90) females. The patients were divided into two groups: 1) patients using full dentures (FD) $(n=37)$ mean of 53.10 years (38 to 80 years), among which $70.3 \%$ (26-37) were females; and 2) patients not using full dentures (NFD) $(n=53)$ mean of 49.26 years (30 to 64 years), of which $60.3 \%$ (32-53) were females.

After DNA extraction, $92.2 \%$ (83/90) of the total samples showed amplification of the human $\beta$-globin gene and were considered valid for analysis. HPV-DNA was detected in $27.7 \%$ (23-83) of all samples. Among the FD group, $41.9 \%(13-31, \mathrm{p}=0.025)$ were positive for HPV-DNA whereas, among the NFD group, the positivity was $19.2 \%$ (10-52) (Figure).

\section{Genotyping}

Considering all patients involved in the study, the most frequently detected viral types were LR-HPV 6 and 11 (39.1\%, 9/23) and HR-HPV 31 (13.0 \%, 3/23).

In the FD group, $38.5 \%$ (5-13) of the HPV-DNA positive samples showed the presence of LR-HPV, and $15.4 \%$ (2-13) showed the presence of HR-HPV. In $7.7 \%$ (1-13) of the samples of this group, multiple infection with LR- and HR-HPV was observed, and in $30.8 \%$ (4-13) the viral types were not identified by the techniques used. These samples were negative by TS-PCR and did not amplify with PGMY09 / 11 primers that did not allow RFLP analysis. The viral types detected in both of the groups were described in Table.

\section{Socio-epidemiological characteristics}

There was no significant difference between the association of age and the presence of HPV DNA among both groups (FD and NFD). Regarding the behavioral characteristics associated with HPV-DNA presence, the variable 'oral sex practice' was significant for all HPV-DNA positive patients and for FD HPV-

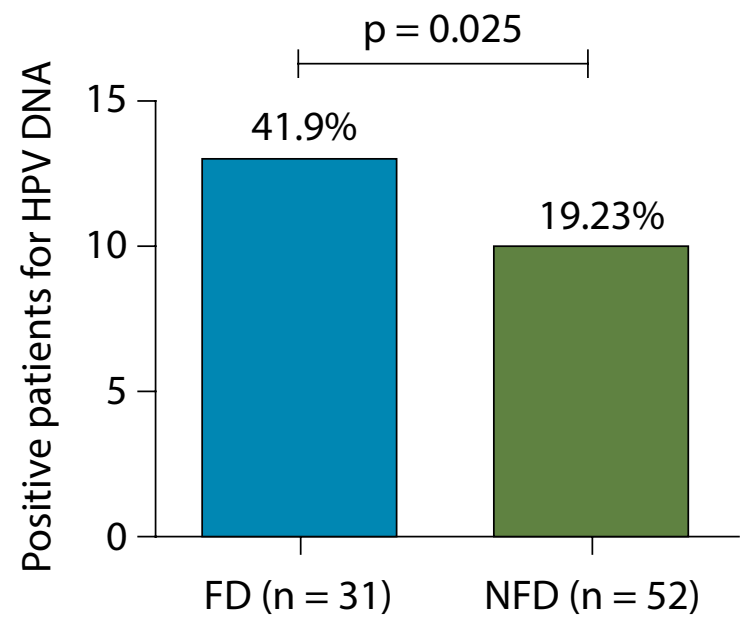

Figure. Distribution of patients positive for HPV-DNA. FD: patients who use full denture and are positive for HPV-DNA. NFD: patients who do not use full denture and are positive for HPV-DNA. ${ }^{*} p=0.025$. Pearson's Chi-square test $\left(x^{2}\right)$. 
Table. Distribution of the viral types according to oncogenic risk.

\begin{tabular}{lcc}
\hline & \multicolumn{2}{c}{ Groups } \\
\cline { 2 - 3 } Viral types & $\mathrm{FD}$ & NFD \\
\cline { 2 - 3 } & $\mathrm{n}(\%)$ & $\mathrm{n}(\%)$ \\
\hline LR-HPV6 & $3(23.1)$ & $4(40.0)$ \\
LR-HPV1 1 & $1(7.7)$ & - \\
LR-HPV40 & $1(7.7)$ & - \\
HR-HPV31 & $2(15.4)$ & - \\
HR-HPV91 & - & $1(10.0)$ \\
HR-HPV45 & - & $1(10.0)$ \\
ND & $4(30.8)$ & $5(50.0)$ \\
\hline
\end{tabular}

LR: Low oncogenic risk; HR: High oncogenic risk; ND: viral types were not genotyped; (-): not found; FD: patients using full dentures that were genotyped $(n=13)$, and NFD: patients not using full dentures that were genotyped $(n=10)$. Some patients had two or more viral types (multiple infection).

DNA positive patients $(4-23, \mathrm{p}=0.01 ; 1-13 ; \mathrm{p}=0.01$ - Fisher's exact test, respectively).

Considering the significant variables 'full denture use' $(p=0.025)$ and 'oral sex practice' $(p=0.01)$, for the group of HPV positive patients, we investigated the variables that would be determinant for HPVDNA presence. Analysis of binary logistic regression revealed that the use of full dentures had an odds ratio of 2.1 to be positive for HPV DNA. $\left(\chi^{2}=9.037\right.$, $\mathrm{DF}=2, \mathrm{p}=0.0011$ ).

\section{Discussion}

The results indicate that patients having full dentures showed a higher frequency of HPV-DNA, the presence of HR-HPV types, and had an odds ratio of 2.1 to be positive for HPV DNA.

Research has shown a great variation in the incidence of HPV infection when detected in the healthy oral mucosa of individuals ( $0 \%$ to $81.1 \%$ ), by means of different methods of collection and detection in various population groups., ${ }^{7,23}$ In the present study, nested PCR revealed a high general prevalence (27.7\%) of HPV-DNA in the healthy oral cavity of adults with or without full dentures, suggesting that this observation included subclinical and/or latent infections, with a low number of viral copies, which is common in the oral cavity. ${ }^{14}$ Most of these infections are likely to regress spontaneously to the point of being undetectable, even by use of the most sensitive methods. ${ }^{9}$ In other anatomical sites, our group found an HPV DNA frequency of about 30\% in cervicovaginal samples of young women (mean age 35 years) and $83.6 \%$ in samples from the glans and coronary sulcus of the penis of heterosexual men (18-65 years). ${ }^{24,25,26}$

Genotyping of the HPV types detected is highly relevant, considering the oral cavity and the potential risk of developing malignant lesions induced by the highly oncogenic types of the virus. The TS-PCR applied in our study aimed to identify the most prevalent types in the asymptomatic oral mucosa and in benign and malignant lesions. ${ }^{1}$ The combination of two methods of genotyping (TS-PCR and RFLP), although still scarce in epidemiological studies, is quite advantageous in the detection of multiple infections.

HPV 6, 11, 16, 18, 31, and 33 were identified in the oral cavity of subjects with and without lesions, and HPV 6 and HPV11 were most commonly found in healthy oral mucosae ( $23.3 \%$ and $6.7 \%$, respectively). ${ }^{27}$ In our study genotypes described as $\alpha$-papillomaviruses were observed, unlike other authors. ${ }^{28,29}$ A prevalence study conducted in the USA, with samples of normal oral mucosa, detected the presence of HR-HPV 16, 66, and 51 and LR-HPV 62, 55, and 89, ${ }^{3}$ whereas in another study, with formalin-fixed paraffin-embedded samples of normal oral mucosa, squamous carcinoma and oral leukoplakias by nested PCR, was detected the presence of types HPV 6, 11, and $16 .^{30}$

In the oral cavity, a broad spectrum of HPV genotypes were previously isolated, and HPV 6, $11,16,18,31,33$, and 35 were also isolated in the healthy oral mucosa. ${ }^{12,13,29}$ HPV 6, 11, 16, and 18 have mucosal affinity and are responsible for most of the lesions both in the oral cavity and cervical region. ${ }^{7,13,31}$ Among the patients who use full dentures, the most frequently observed types were HPV 6, 11, 31, 40, 45 , and 91. LR-HPV presented a higher frequency (16.1\%) compared to that of HR-HPV (6.5\%). These results contradict the findings in the literature, which describe HPV 16 and 18 as the most common types found in the oral cavity, which, because of their highly oncogenic potential, are considered possible 
risk factors for the development of carcinoma in the oral cavity. $2,4,6,9,10,13,32$

Several authors report that HPV can infect cells of the basal layer of the epithelium provided that there is a rupture, for example, micro traumas in the epithelium. ${ }^{1,10,18}$ In this study we found that $41.9 \%$ of patients with full dentures were positive for HPVDNA, an index higher than the patients who did not use full dentures $(p=0.025)$. These results confirm the expectancy of potentiation of infection by micro traumas caused in the mucosa by the dentures and the consequent facilitation of viral infection.

Transmission of HPV can occur through contact between the injured and healthy mucosa, and for oral infection, several forms of contamination are considered relevant, such as oral sex, autoinoculation, and others. However, abrasion of the mucosa with exposure of the epithelial basal layer cells is necessary for the virus to enter the host cel..$^{4,9,13,14}$ The use of dentures for a long time, often ill adapted, poor hygiene conditions, and other co-factors increase the risk of infection by this virus. ${ }^{4,710,32}$ Although in our study age and other factors were not significant, we cannot rule out its possible influence.

Indicators related to sexual activity, such as the number of recent sexual partners, the number of lifetime partners, and the patient's age at the time of the first sexual intercourse have been consistently reported as being the most relevant risk factors for HPV infection. Sexual behavior is crucially associated with HPV infection, because direct contact with the epithelium without the use of adequate protection is a key factor. ${ }^{8,14,33}$ In this study, the practice of oral sex was associated with HPV infection in both FD and NFD groups, corroborating the importance of 'oral sex practice' as cofactor in transmitting the HPV to this anatomical site.

When the variables 'use of full dentures' and 'oral sex practice' were analyzed together, the former represented an odds ratio of 2.1 to be positive for HPV DNA. The literature shows that people with poor oral health and people with oral disease are significantly more susceptible to oral infections, including those caused by HPV., ${ }^{4,10,32}$ Studies have reported that in patients with poor oral health, the prevalence of HPV in oral infection is high. ${ }^{10}$ Patients with periodontal disease or other tooth-related problems are also frequently affected by HPV infection. ${ }^{7}$ In addition, the relationship between the number of teeth lost and oral HPV infection has also been studied. 6,19,20,34 These findings together suggest that poor oral health predisposes to HPV infection.

In conclusion, this study showed the highest HPV-DNA presence in patients with full dentures, including the presence of HR - viral types and infection by more than one viral type. In addition to the use of full dentures, the practice of oral sex was also considered associated to HPV-DNA presence, emphasizing the importance of sexual contact as a mode of transmission. Our results indicate the need for periodic follow-up and orientation to the patients with full dentures in order to preserve basic oral health conditions and also to monitor the appearance of lesions with malignant potential.

\section{References}

1. Kreimer AR, Bhatia RK, Messeguer AL, González P, Herrero R, Giuliano AR. Oral human papillomavirus in healthy individuals: a systematic review of the literature. Sex Transm Dis. 2010 Jun;37(6):386-91. https://doi.org/10.1097/OLQ.0b013e3181c94a3b

2. Khode SR, Dwivedi, RC, Rhys-Evans P, Kazi, R. Exploring the link between human papilloma virus and oral and oropharyngeal cancers. J Cancer Res Ther. 2014 Jul-Sep;10(3):492-8. https://doi.org/10.4103/0973-1482.138213

3. Gravitt PE, Peyton CL, Alessi TQ, Wheeler CM, Coutlée F, Hildesheim A, et al. Improved amplification of genital human papillomaviruses. J Clin Microbiol. 2000 Jan;38(1):357-61.

4. Yakin M, Gavidi RO, Cox B, Rich A. Oral cancer risk factors in New Zealand. N Z Med J. 2017 Mar;130(1451):30-8.

5. Gillison ML, Koch WM, Capone RB, Spafford M, Westra WH, Wu L, et al. Evidence for a causal association between human papillomavirus and a subset of head and neck cancers. J Natl Cancer Inst. 2000 May;92(9):709-20.

https://doi.org/10.1093/jnci/92.9.709 
6. Rivero ERC, Nunes FD. HPV in oral squamous cell carcinomas of a Brazilian population: amplification by PCR. Braz Oral Res. 2006 Mar;20(1):21-4. https://doi.org/10.1590/S1806-83242006000100005

7. Bui TC, Markham CM, Ross MW, Mullen PD. Examining the association between oral health and oral HPV infection. Cancer Prev Res (Phila). 2013 Sep;6(9):917-24. https://doi.org/10.1158/1940-6207.CAPR-13-0081

8. Chen F, Yan L, Liu F, Huang J, Liu F, Wu J, et al. Oral human papillomavirus infection, sexual behaviors and risk of oral squamous cell carcinoma in southeast of China: a case-control study. J Clin Virol. 2016 Dec;85:7-12. https://doi.org/10.1016/i.jcv.2016.10.011

9. Migaldi M, Pecorari M, Forbicini G, Nanni N, Grottola A, Grandi T, et al. Low prevalence of human papillomavirus infection in the healthy oral mucosa of a Northern Italian population. J Oral Pathol Med. 2012 Jan;41(1):16-20. https://doi.org/10.1111/j.1600-0714.2011.01062.x

10. Perry BJ, Zammit AP, Lewandowski AW, Bashford JJ, Dragovic AS, Perry EJ, et al. Sites of origin of oral cavity cancer in nonsmokers vs smokers: possible evidence of dental trauma carcinogenesis and its importance compared with human papillomavirus. JAMA Otolaryngol Head Neck Surg. 2015 Jan;141(1):5-11. https://doi.org/10.1001/jamaoto.2014.2620

11. Doorbar J, Quint W, Banks L, Bravo IG, Stoler M, Broker TR, et al. The biology and life-cycle of human papillomaviruses. Vaccine. 2012 Nov;30(5 Suppl 5):F55-70. https://doi.org/10.1016/i.vaccine.2012.06.083

12. Doorbar J, Egawa N, Griffin H, Kranjec C, Murakami I. Human papillomavirus molecular biology and disease association. Rev Med Virol. 2015 Mar;25(1 Suppl 1):2-23. https://doi.org/10.1002/rmv.1822

13. Correnti M, Rivera H, Cavazza ME. Detection of human papillomaviruses of high oncogenic potential in oral squamous cell carcinoma in a Venezuelan population. Oral Dis. 2004 May;10(3):163-6. https://doi.org/10.1046/i.1601-0825.2003.00989.x

14. Colpani V, Bidinotto AB, Falavigna M, Giozza SP, Benzaken AS, Pimenta C, et al. Prevalence of papillomavirus in Brazil: a systematic review protocol. BMJ Open. 2016 Nov;6(11):e011884. https://doi.org/10.1136/bmjopen-2016-011884

15. McQuillan G, Kruszon-Moran D, Markowitz LE, Unger ER, Paulose-Ram R. Prevalence of HPV in adults aged 18-69: United States, 2011-2014. NCHS Data Brief. 2017 Apr;(280):1-8.

16. Anderson KM, Perez-Montiel D, Miles L, Allen CM, Nuovo GJ. The histologic differentiation of oral condyloma acuminatum from its mimics. Oral Surg Oral Med Oral Pathol Oral Radiol Endod. 2003 Oct;96(4):420-8. https://doi.org/10.1016/S1079-2104(03)00301-9

17. Bouda M, Gorgoulis VG, Kastrinakis NG, Giannoudis A, Tsoli E, Danassi-Afentaki D, et al. "High risk" HPV types are frequently detected in potentially malignant and malignant oral lesions, but not in normal oral mucosa. Mod Pathol. 2000 Jun;13(6):644-53. https://doi.org/10.1038/modpathol.3880113

18. Kim SM. Human papilloma virus in oral cancer. J Korean Assoc Oral Maxillofac Surg. 2016 Dec;42(6):327-36. https://doi.org/10.5125/jkaoms.2016.42.6.327

19. Ribeiro MG, Marcolino LD, Ramos BR, Miranda EA, Trento CL, Jain S, et al. High prevalence of human papillomavirus (HPV) in oral mucosal lesions of patients at the Ambulatory of Oral Diagnosis of the Federal University of Sergipe, Northeastern Brazil. J Appl Oral Sci. 2017 Jan-Feb;25(1):69-74. https://doi.org/10.1590/1678-77572016-0313

20. Fuessel Haws AL, He Q, Rady PL, Zhang L, Grady J, Hughes TK, et al. Nested PCR with the PGMY09/11 and GP5(+)/6(+) primer sets improves detection of HPV DNA in cervical samples. J Virol Methods. 2004 Dec;122(1):87-93. https://doi.org/10.1016/i.jviromet.2004.08.007

21. Guo M, Sneige N, Silva EG, Jan YJ, Cogdell DE, Lin E, et al. Distribution and viral load of eight oncogenic types of human papillomavirus (HPV) and HPV 16 integration status in cervical intraepithelial neoplasia and carcinoma. Mod Pathol. 2007 Feb;20(2):256-66. https://doi.org/10.1038/modpathol.3800737

22. Nobre RJ, Almeida LP, Martins TC. Complete genotyping of mucosal human papillomavirus using a restriction fragment length polymorphism analysis and an original typing algorithm. J Clin Virol. 2008 May;42(1):13-21. https://doi.org/10.1016/j.jcv.2007.11.021

23. Carvalho NO, Castillo DM, Perone C, Januário JN, Melo VH, Brasileiro Filho G. Comparison of HPV genotyping by type-specific PCR and sequencing. Mem Inst Oswaldo Cruz. 2010 Feb;105(1):73-8. https://doi.org/10.1590/S0074-02762010000100011

24. Campos KL, Machado AP, Almeida FG, Bonin CM, Prata TT, Almeida LZ, et al. Good agreements between self and clinician-collected specimens for the detection of human papillomavirus in Brazilian patients. Mem Inst Oswaldo Cruz. 2014 Jun;109(3):352-5. https://doi.org/10.1590/0074-0276130397

25. Almeida FG, Machado AP, Fernandes CE, Ferreira AT, Padovani CT, Tozetti IA. Molecular epidemiology of the human papillomavirus infection in self-collected samples from young women. J Med Virol. 2014 Feb;86(2):266-71. https://doi.org/10.1002/jmv.23725

26. Marques SM, Marques DF, Fernandes CES, Scapulatempo ID, Ferreira AM, Padovani CT, et al. Type-specific human papillomavirus infection among heterosexual males examined by peniscopy. Sex Transm Infect. 2013 Feb;89(1):82. https://doi.org/10.1136/sextrans-2012-050717

27. Llamas-Martínez S, Esparza-Gómez G, Campo-Trapero J, Cancela-Rodríguez P, Bascones-Martínez A, Moreno-López LA, et al. Genotypic determination by PCR-RFLP of human papillomavirus in normal oral mucosa, oral leukoplakia and oral squamous cell carcinoma samples in Madrid (Spain). Anticancer Res. 2008 Nov-Dec;28 6A:3733-41. 
28. Bottalico D, Chen Z, Dunne A, Ostoloza J, McKinney S, Sun C, et al. The oral cavity contains abundant known and novel human papillomaviruses from the Betapapillomavirus and Gammapapillomavirus genera. J Infect Dis. 2011 Sep;204(5):787-92. https://doi.org/10.1093/infdis/jir383

29. de Villiers EM, Fauquet C, Broker TR, Bernard HU, zur Hausen H. Classification of papillomaviruses. Virology. 2004 Jun;324(1):17-27. https://doi.org/10.1016/j.virol.2004.03.033

30. Kristoffersen AK, Enersen M, Kverndokk E, Sunde PT, Landin M, Solheim T, et al. Human papillomavirus subtypes in oral lesions compared to healthy oral mucosa. J Clin Virol. 2012 Apr;53(4):364-6. https://doi.org/10.1016/i.jcv.2011.12.023

31. Elamin F, Steingrimsdottir H, Wanakulasuriya S, Johnson N, Tavassoli M. Prevalence of human papillomavirus infection in premalignant and malignant lesions of the oral cavity in U.K. subjects: a novel method of detection. Oral Oncol. 1998 May;34(3):191-7. https://doi.org/10.1016/S1368-8375(97)00081-X

32. Kumaraswamy KL, Vidhya M. Human papilloma virus and oral infections: an update. J Cancer Res Ther. 2011 Apr-Jun;7(2):120-7. https://doi.org/10.4103/0973-1482.82915

33. D'Souza G, Agrawal Y, Halpern J, Bodison S, Gillison ML. Oral sexual behaviors associated with prevalent oral human papillomavirus infection. J Infect Dis. 2009 May;199(9):1263-9. https://doi.org/10.1086/597755

34. Sánchez-Vargas LO, Díaz-Hernández C, Martinez-Martinez A. Detection of Human Papilloma Virus (HPV) in oral mucosa of women with cervical lesions and their relation to oral sex practices. Infect Agent Cancer. 2010 Dec;5(1):25. https://doi.org/10.1186/1750-9378-5-25 